\title{
Analisis Penggunaan Metode Pencatatan Cash Basis dan Accrual Basis Pada Transaksi- transaksi di Bank Syariah
}

\author{
Ayus Ahmad Yusuf \\ (Dosen Fakultas Syariah IAIN Syekh Nurjati Cirebon) \\ email : ayussyusuf@yahoo.co.id \\ Neni Nurhayati \\ (Dosen Fakultas Ekonomi Universitas Kuningan) \\ email : neniyati@gmail.com
}

\begin{abstract}
Abstrak
Metode pencatatan Cash Basis adalah basis akuntansi yang mengakui pengaruh transaksi dan peristiwa lainnya pada saat kas atau setara kas diterima atau dibayar yang digunakan untuk pengakuan pendapatan, belanja dan pembiayaan, sedangkan pendapatan dan beban dalam accrual basis diakui pada saat terjadinya transaksi dan dicatat untuk suatu periode, sehingga mengakui adanya konsep realisasi dan penyesuaian. Saat ini bank syariah secara umum telah mencatat transaksi-transaksi berdasarkan metode pencatatan atas dasar akrual, kecuali Laporan Arus Kas dan penghitungan pendapatan untuk tujuan pembagian hasil usaha. Metode cash basis mereka gunakan dalam perhitungan bagi hasil yang akan dibayarkan dengan cara merekonsiliasi pendapatan atas dasar akrual dari setiap transaksi menjadi bentuk pencatatan basis kas, Hal ini dilakukan karena perbankan syariah tidak dibenarkan mendistribusikan pendapatan atau keuntungan yang bukan menjadi hak perbankan syariah. Laporan ini akan mengeliminasi pendapatan yang diperoleh berdasarkan basis akrual dan mengakui pendapatan yang seharusnya diperoleh pada periode berjalan. Bank syariah dalam pencatatan transaksi-transaksinya telah mematuhi prinsip-prinsip syariah yaitu dengan berpedoman pada PSAK No. 101-110 tentang Perbankan Syariah. Yaitu secara umum bahwa transaksi-transaksi di bank syariah dicatatat berdasarkan metode pencatatan atas dasar akrual, kecuali Laporan Arus Kas dan penghitungan pendapatan untuk tujuan pembagian hasil usaha. Dalam penghitungan pembagian hasil usaha didasarkan pada pendapatan yang benar-benar terjadi yaitu dengan menggunakan metode pencatatan cash basis.
\end{abstract}

Keywords: Cash Basis, Accruel Basis dan Bank Syariah

\begin{abstract}
Recording method Cash Basis is the basis of accounting that recognizes the effect of transactions and other events on a cash or cash equivalent is received or paid are used for the recognition of revenue, expenditure and financing, while revenues and expenses in the accrual recognized at the transaction date and recorded for a period, thus acknowledging the existence of the concept of realization and adjustment. Currently the Islamic banks in general have recorded transactions based method of recording on an accrual basis, except Cash Flow Statement and income calculation for the purpose of sharing the results of operations. Cash basis method they use in calculating the results of which will be paid by way of reconciling revenue on the accrual basis of each transaction into a form of recording cash basis, This is done because Islamic banking is not allowed to distribute income or profit that
\end{abstract}


does not belong to Islamic banking. This report would eliminate the income earned on the accrual basis and recognizes revenue that should be obtained in the current period. Islamic banks in recording transactions-transactions are in compliance with Islamic principles that guided by SFAS No. 101-110 on Islamic Banking. Ie in general that the transactions in Islamic banks dicatatat based method of recording on an accrual basis, except Cash Flow Statement and income calculation for the purpose of sharing the results of operations. In calculating the distribution of the results of operations are based on the income that is really happening is by using the cash basis method of recording.

Keywords: Cash Basis, Basis and Bank Syariah Accruel 


\section{Pendahuluan}

Sejarah perkembangan sistem perbankan syariah di Indonesia mencerminkan adanya suatu keinginan serta aspirasi dari masyarakat Indonesia untuk memiliki sebuah alternatif sistem perbankan yang adil, yaitu melalui penerapan sistem bagi hasil yang menguntungkan kedua belah pihak, yaitu nasabah dan bank. Keberadaan bank syariah di Indonesia telah di atur dalam Undang-undang yaitu UU No. 10 tahun 1998 tentang Perubahan dari UU No. 7 tahun 1992 tentang Perbankan yang merupakan pintu gerbang dimulainya perbankan syariah di Indonesia. Namun, Undang-Undang tersebut belum memberikan landasan hukum yang cukup kuat terhadap pengembangan bank syariah karena belum secara tegas mengatur mengenai keberadaan bank berdasarkan prinsip syariah itu sendiri, melainkan bank bagi hasil. Bank bagi hasil yang dimaksudkan dalam undang-undang tersebut belum mencakup secara tepat pengertian bank syariah yang ternyata memiliki sebuah cakupan yang lebih luas bila dibandingkan dengan bank bagi hasil.

Tahun 1998 dengan diberlakukannya UU No. 10 Tahun 1998 tentang perubahan UU No. 7 Tahun 1992 tentang perbankan yang diikuti dengan dikeluarkannya sejumlah ketentuan pelaksanaan dalam bentuk SK Direksi BI mulai dianggap telah memberikan landasan hukum yang lebih kuat dan kesempatan yang luas bagi pengembangan perbankan syariah di Indonesia.

Melalui perubahan atas Undangundang No. 7 Tahun 1992 tentang Perbankan menjadi Undang-undang No.10 Tahun 1998, keberadaan sistem perbankan syariah semakin di dorong perkembangannya di Indonesia. Undang-Undang tersebut memberikan pengakuan yang lebih tegas mengenai keberadaan dan perlunya bankbank berdasarkan prinsipsyariah, serta memberikan peluang yang lebih besar bagi pengembangan bank-bank tersebut. UndangUndang tersebut antara lain mengatur mengenai dimungkinkannya bank-bank konvensional mendirikan cabang-cabang yang beroperasi berdasarkan prinsip syariah. Dasar hukum yang lebih jelas ini serta peluang yang diciptakannya akan cenderung mendorong tumbuhnya bank Islam atau cabang syariah dari bank-bank konvensional pada masa mendatang.

Pertumbuhan perbankan syariah di Indonesia relatif cepat dalam lima tahun terakhir, dengan rata-rata pertumbuhan asset mencapai 40 persen. Posisi asset perbankan syariah per September 2011 telah mencapai Rp 126 triliun. Dengan posisi itu, perbankan syariah Indonesia menduduki posisi keempat dunia setelah Iran, Malaysia, dan Arab Saudi. Peningkatan aset tersebut sejalan dengan kinerja penyaluran pembiayaan serta penghimpunan dana pihak ketiga (DPK) yang dilakukan oleh bank umum syariah, unit usaha syariah, dan bank pembiayaan rakyat syariah. Begitu pun untuk di Jawa Barat, pertumbuhan perbankan syariah terus mengalami peningkatan dari tahun ketahun dan mengalahkan bank konvensional. Pada tahun 2011, perbankan syariah mengalami pertumbuhan 58,9 persen, sementara bank konvensional hanya 23 persen saja.

Dengan semakin tingginya pertumbuhan perbankan syariah saat ini, maka perlu didukung oleh penerapan metode dan praktek akuntansi yang sesuai dengan Etika bisnis Islami. Oleh karena itu, pada tahun 2003, IAI menyususn PSAK No. 59 tentang perbankan Syariah yang kemudian dikembangkan menjadi PSAK 101110..Namun PSAK itu pula yang kini tengah menjadi perbincangan ramai di kalangan para peminat dan pengamat ekonomi syariah.

Fenomena yang terjadi dalam bank syariah adalah PSAK 101-110 yang saat ini diterapkan dinilai tidak konsisten dengan jiwa syariah khususnya dalam filosofinya. Menurut Nasrullah Djamil sistem ini masih kental mengadopsi filosofi akuntansi konvensional yang menggunakan sistem acrual basis. Sistem ini kurang pas dengan jiwa syariah karena menempatkan pendapatan yang belum nyata dalam laporan keuangan. 
Penerapan sistem cash basis pada bank syariah sangat fundamental karena bank syariah tidak akan mengalami negative spread karena menggunakan prinsip bagi hasil. Jadi jika sistem cash basis ini dihilangkan, ciri akuntansi syariah ikut hilang. Sistem akuntansi dasar akrual (acrual basis) tidak sensitif dalam mencegah terjadinya kejahatan keuangan. Kasus WorldCom, Enron, Xerox semula berawal dari penerapan metode pencatatan atas dasar akrual. Laporan keuangan mereka bagus, tapi cash flow mereka buruk. Itu terjadi, karena pendekatan dasar akrual memang membuka peluang trik-trik curang dalam pembukuan. Tragedi WorldCom terjadi karena akuntannya memanfaatkan lubanglubang dasar akrual, yang pada akhirnya merugikan para pemilik saham. Kebangkrutan itu disebabkan banyak keuntungan yang masih berbentuk potensi dibukukan dan diakui sebagai pendapatan mereka.

Beberapa pemerhati akuntansi Islam salah satunya mantan Direktur Utama Bank Muamalat, Zainulbahar Noor berpendapat bahwa dalam dasar akrual mengandung unsur gharar dimana dinyatakan bahwa system accrual basis, telah mengakui adanya pendapatan yang terjadi di masa yang akan dating. Aji Dedi berpendapat asumsi tersebut sangat bertentangan dengan prinsip dan akhlak syariah bahkan tujuan laporan keuangan akuntansi syariah ${ }^{1}$. Mereka yang tidak menerima konsep akrual juga menyatakan bahwa konsep ini tidak dapat dipakai sebagai cara menghitung zakat mengingat zakat harus dibayar berdasarkan kekayaan yang telah diterima manfaatnya (menurut Mazhab Maliki), dan juga bagi hasil atas mudharabah didasarkan atas keuntungan kas yang diterima (menurut Mazhab Syafi'i) dikutip dari Nurhayati dan Wasilah, 2008. Dasar ini telah menjawab

\footnotetext{
${ }^{1}$ Aji Dedi Mulawarman,. 2007. Menggagas laporan arus kas syariah berbasis ma'isyah diangkat dari Habitus Bisnis Muslim Indonesia. Makalah disampaikan dalam Simposium Nasional Akuntansi X Tahun 2007
}

penggunaan pendapat Khalifah Umar bin Khattab yaitu mengenai penilaian kekayaan untuk perhitungan zakat sebagai pengesahan penerapan akuntansi akrual.

Sedangkan menurut Lathifah Ifah (2007) sistem accrual basis kurang pas dengan jiwa syariah karena menempatkan pendapatan yang belum nyata dalam laporan keuangan, Penerapan sistem cash basis sangat fundamental. Seperti halnya bank syariah tidak bisa mengalami negative spread karena menggunakan prinsip bagi hasil. Jadi kalau sistem cash basis ini dihilangkan, ciri akuntansi syariah ikut hilang karena pendekatan accrual basis memang membuka peluang trik-trik curang dalam pembukuan. ${ }^{2}$

Dari pihak pendukung basis akrual seperti Accounting and Auditing Organization for Islamic Financial Institution (AAOIFI) dalam Accounting and Auditing Standars for Islamic Financial Institutional beralasan dengan landasan yang mengacu pada pendapat dari Khalifah Umar bin Khatab: "Nilailah barang daganganmu dan bayarlah zakatnya (jika telah masuki haulnya)". "Hal ini memberi implikasi bahwa zakat harus dibayar atas kekayaan yang meningkat dan konsep akrual ini dinilai paling baik untuk menilai kekayaan.

Dalam Al Quran surat Al-Baqarah ayat 282 sebenarnya Islam menerima konsep accrual basis namun dalam hal sesuatu yang belum pasti kita tidak bias memastikannya misalnya apakah bagi hasil benar-benar diterima. Dewan Syariah Nasional akhirnya menetapkan bahwa dalam kedua metode ini terdapat manfaat dan mudharat masingmasing.

Beberapa bank Islam mengakui bahwa pendapatan menggunakan dasar akrual (accrual basis) yaitu pendapatan diakui pada saat nasabah atau klien telah

\footnotetext{
${ }^{2}$ Lathifah, ifah. 2007. Model Alternatif Akuntansi Syariah dalam Pelaporan Keuangan, Bandung : Ascarya, h. 125

${ }^{3}$ Nurhayati, Sri \& Wasilah. 2008. Akuntansi Islam di

Indonesia. Jakarta: Salemba Empat, h. 102
} 
melunasi seluruh pinjaman atau melunasi semua cicilannya. Sedangkan pada bank Islam yang lain mengakui pendapatan dengan menggunakan dasar kas (cash basis) yaitu pendapatan diakui pada saat bank menerima kas dari nasabah atau klien ketika mengangsur ataupun mencicil pinjamannya (FAO-IBFI, 1998, 146).

Situasi tersebut diatas memperlihatkan bahwa bank-bank Islam ternyata belum sepenuhnya memakai satu standar yang baku sebagai acuan dalam operasionalnya dan selanjutnya akan mengurangi kegunaan informasi keuangan yang dihasilkan oleh bank Islam bagi para pemakai laporan keuangan. Oleh Karenanya kebutuhan dalam menetapkan dasar dan metode pencatatan akuntansi menjadi sangat penting dan harus disesuaikan dengan ketentuan-ketentuan syariah yang telah diatur dalam "Financial Accounting Standards For Islamic Bank and Financial Institutions" (FAS - IBFI).

Sejalan dengan tujuan penelitian, maka penelitian ini berbentuk studi kasus dengan menggunakan penelitian deskriptif analisis bertujuan untuk menggambarkan penerapan model pencatatan cash basis dan akrual basis pada transaksi-transaksi di bank syariah. Teknik pengumpulan data yang digunakan adalah dengan penelitian lapangan yakni dengan mengadakan pengamatan secara langsung, observasi, dokumentasi dan wawancara dengan karyawan yang berhubungan dengan penelitian ini. Sampel yang digunakan adalah 3 (tiga) bank syariah yang ada di Kabupaten Kuningan yaitu Bank Muamalat Indonesia, Bank Syariah Mandiri, dan Bank Jabar Syariah.

\section{Pembahasan}

Anthony menjelaskan cash basis, sebagai berikut:

An alternative way of measuring
income is called cash-basis
accounting. With this method, sales
are not recorded until the period in
which they are received in cash.
Similarly, costs are subtracted from
income is called cash-basis accounting. With this method, sales are not recorded until the period in Similarly, costs are subtracted from sales in the period in which they are paid for by cash disbursement. Thus, neither the realization nor matching concept applies in cashbasis accounting. ${ }^{4}$

Cash Basis merupakan salah satu konsep yang sangat penting dalam akuntansi, dimana pencatatan basis kas adalah teknik pencatatan ketika transaksi terjadi dimana uang benar-benar diterima atau dikeluarkan. Dengan kata lain Akuntansi Cash Basis adalah basis akuntansi yang mengakui pengaruh transaksi dan peristiwa lainnya pada saat kas atau setara kas diterima atau dibayar yang digunakan untuk pengakuan pendapatan, belanja dan pembiayaan.

Cash Basis akan mencatat kegiatan keuangan saat kas atau uang telah diterima misalkan perusahaan menjual produknya akan tetapi uang pembayaran belum diterima maka pencatatan pendapatan penjualan produk tersebut tidak dilakukan, jika kas telah diterima maka transaksi tersebut baru akan dicatat seperti halnya dengan "dasar akrual" hal ini berlaku untuk semua transaksi yang dilakukan, kedua teknik tersebut akan sangat berpengaruh terhadap laporan keuangan, jika menggunakan dasar akrual maka penjualan produk perusahaan yang dilakukan secara kredit akan menambah piutang dagang sehingga berpengaruh pada besarnya piutang dagang sebaliknya jika yang di pakai basis kas maka piutang dagang akan dilaporkan lebih rendah dari yang sebenarnya terjadi.

Cash Basis mendasarkan konsepnya pada dua pilar yaitu :

1. Pengakuan Pendapatan

Saat pengakuan pendapatan pada cash basis adalah pada saat perusahaan menerima pembayaran secara kas. Dalam konsep cash basis menjadi hal yang kurang penting mengenai kapan munculnya hak untuk menagih.

\footnotetext{
${ }^{4}$ Harahap, Sofyan S. 2001. Menuju Perumusan Teori Akuntansi Islam. Pustaka Quantum. Jakarta.h. 95
} 
Sehingga dalam cash basis kemudian muncul adanya metode penghapusan piutang secara langsung dan tidak mengenal adanya estimasi piutang tak tertagih.

2. Pengakuan Biaya

Pengakuan biaya dilakukan pada saat sudah dilakukan pembayaran secara kas. Sehingga dengan kata lain, pada saat sudah diterima pembayaran maka biaya sudah diakui pada saat itu juga.

Disamping itu, pencatatan akuntansi dengan metode cash basis juga mempunyai beberapa keunggulan dan kelemahan yaitu sebagai berikut :

Keunggulan metode pencatatan akuntansi secara Cash Basis adalah:

1. Metode Cash basis digunakan untuk pencatatan pengakuan pendapatan, belanja dan pembiayaan.

2. Beban/biaya belum diakui sampai adanya pembayaran secara kas walaupun beban telah terjadi, sehingga tidak menyebabkan pengurangan dalam penghitungan pendapatan.

3. Pendapatan diakui pada saat diterimanya kas,sehingga benar-benar mencerminkan posisi yang sebenanya.

4. Penerimaan kas biasanya diakui sebagai pendapatan.

5. Laporan Keuangan yang disajikan memperlihatkan posisi keuangan yang ada pada saat laporan tersebut.

6. Tidak perlunya suatu perusahaan untuk membuat pencadangan untuk kas yang belum tertagih.

Sedangkan kelemahan metode pencatatan akuntansi secara Cash Basis adalah:

1. Metode Cash basis tidak mencerminkan besarnya kas yang tersedia.

2. Akan dapat menurunkan perhitungan pendapatan bank, karena adanya pengakuan pendapatan sampai diterimanya uang kas.

3. Adanya penghapusan piutang secara langsung dan tidak mengenal adanya estimasi piutang tak tertagih.
4. Biasanya dipakai oleh perusahaan yang usahanya relative kecil seperti toko, warung, mall retail dan praktek kaum spesialis seperti dokter, dll

5. Setiap pengeluaran kas diakui sebagai beban.

6. Sulit dalam melakukan transaksi yang tertunda pembayarannya, karena pencatatan diakui pada saat kas masuk atau keluar.

7. Sulit bagi manajemen untuk menentukan suatu kebijakan kedepannya karena selalu berpatokan kepada kas.

Sehingga dengan kata lain metode pencatatan Cash Basis adalah basis akuntansi yang mengakui pengaruh transaksi dan peristiwa lainnya pada saat kas atau setara kas diterima atau dibayar yang digunakan untuk pengakuan pendapatan, belanja dan pembiayaan.

Berdasarkan keterangan tersebut di atas, maka dapat disimpulkan bahwa pendapatan dan beban dalam cash basis diakui pada saat kas diterima atau dibayar.

Terdapat beberapa artikel terkait dengan penggunaan metode Cash Basis diantaranya adalah: Dasar Akrul VS Dasar Kas oleh Anhar, Cash atau Accrual oleh Cecep Maskanul Hakim, Dasar Akrual VS Dasar Kas Studi pendapat Para Ahli oleh Muhammad Surya, PSAK 59 : Syukur Namun Perlu Disempurnakan, Accrual dan Cash Basis Masing-masing Ada Tempatnya, dan Antara Cash dan Accrual Basis oleh Dedy. Masing-masing artikel tersebut dibahas tentang bagaimana penggunaan serta kelemahan dan keunggulan dari masingmasing metode pencatatan akuntansi yaitu metode Cash dan Accrual Basis.

\section{Kajian Tentang Metode Pencatatan Accrual Basis}

Anthony menjelaskan tentang accrual basis sebagai berikut:

Central to accrual accounting are the realization concept and the 
matching consept. Accrual accounting measures income for a period as the difference between the revenues recognized in that period and the expenses that are matched with those revenues. As noted previously, the period's revenues generally are not the same as the period's cash receipt from customer, and the period's expenses generally are not same as the period's cash disbursements.

Accrual Basis adalah suatu basis akuntansi dimana transaksi ekonomi dan peristiwa diakui, dicatat, dan disajikan dalam laporan keuangan pada saat terjadinya transaksi tersebut tanpa memperhatikan waktu kas diterima atau dibayar.Pencatatan menggunakan metode ini mengakui beban pada saat transaski terjadi walaupun kas belum dibayarkan.Begitu pula dengan pendapatan. Pendapatan dicatat pada saat transaksi pendapatan terjadi walaupun kas atas transaksi pendapatan tersebut baru diterima bulan depan. Dalam hal ini maka dapat disimpulkan bahwa pencatatan menggunakan accrual basis lebih mencermikan keadaan perusahaan dan lebih dapat mengukur kinerja perusahaan.

Teknik accrual basis memiliki fitur pencatatan dimana transaksi sudah dapat dicatat karena transaksi tersebut memiliki implikasi uang masuk atau keluar di masa depan. Transaksi dicatat pada saat terjadinya walaupun uang belum benar - benar diterima atau dikeluarkan.

Dengan kata lain basis akrual digunakan untuk pengukuran aset, kewajiban dan ekuitas dana. Jadi accrual basis adalah basis akuntansi yang mengakui pengaruh transaksi dan peristiwa lainnya pada saat transaksi dan peristiwa itu terjadi tanpa memperhatikan saat kas atau setara kas diterima atau dibayar.

Accrual Basis juga mendasarkan konsepnya pada dua pilar yaitu:

1. Pengakuan Pendapatan

Saat pengakuan pendapatan pada accrual basis adalah pada saat perusahaan mempunyai hak untuk melakukan penagihan dari hasil kegiatan perusahaan. Dalam konsep accrual basis menjadi hal yang kurang penting mengenai kapan kas benarbenar diterima. Sehingga dalam accrual basis kemudian muncul adanya estimasi piutang tak tertagih, karena penghasilan sudah diakui padahal kas belum diterima.

2. Pengakuan Biaya

Pengakuan biaya dilakukan pada saat kewajiban membayar sudah terjadi. Sehingga dengan kata lain, pada saat kewajiban membayar sudah terjadi, maka titik ini dapat dianggap sebagai starting point munculnya biaya meskipun biaya tersebut belum dibayar.

Metode pencatatan akuntansi secara akrual juga memiliki keunggulan dan kelemahan diantaranya adalah:

Keunggulan metode pencatatan akuntansi secara Accrual Basis adalah:

1. Metode aacrual basis digunakan untuk pengukuran aset, kewajiban dan ekuitas dana.

2. Beban diakui saat terjadi transaksi, sehingga informasi yang diberikan lebih handal dan terpercaya.

3. Pendapatan diakui saat terjadi transaksi, sehingga informasi yang diberikan lebih handal dan terpecaya walaupun kas belum diterima.

4. Banyak digunakan oleh perusahan-perusahana besar (sesuai dengan Ketentuan Standar Akuntansi Keuangan dimana mengharuskan suatu perusahaan untuk menggunakan basis akural).

5. Piutang yang tidak tertagih tidak akan dihapus secara langsung tetapi akan dihitung kedalam estimasi piutang tak tertagih.

6. Setiap penerimaan dan pembayaran akan dicatat kedalam 
masing-masing akun sesuai dengan transaksi yang terjadi.

7. Adanya peningkatan pendapatan perusahaan karena kas yang belum diterima dapat diakui sebagai pendapatan.

8. Laporan keuangan dapat dijadikan sebagai pedoman manajemen dalam menentukan kebijakan perusahaan kedepanya.

9. Adanya pembentukan pencandangan untuk kas yang tidak tertagih, sehingga dapat mengurangi risiko kerugian.

Sedangkan kelemahan pencatatan akuntansi secara accrual basis adalah sebagai berikut:

1. Biaya yang belum dibayarkan secara kas, akan dicatat efektif sebagai biaya sehingga dapat mengurangi pendapatan perusahaan.

2. Adanya resiko pendapatan yang tak tertagih sehingga dapat membuat mengurangi pendapatan perusahaan.

3. Dengan adanya pembentukan cadangan akan dapat mengurangi pendapatan perusahaan.

4. Perusahaan tidak mempunyai perkiraan yang tepat kapan kas yang belum dibayarkan oleh pihak lain dapat diterima.

Adapun tujuan penggunaan metode pencatatan accrual basis adalah:

1. Meningkatkan efisiensi dan efektivitas ( penganggaran, akuntansi dan pelaporan)

2. Mengendalikan penyajian fiscal, manajemen asset

3. Informasi yang lebih lengkap untuk pengambilan keputusan.

4. Transfaransi yang lebih luas atas biaya pelayanan yang dilakukan perusahaan.

Sedangkan manfaat dari penerapan metode pencatatan accrual basis adalah:
1. Gambaran yang utuh atas posisi keuangan

2. Informaasi yang sebenarnya kewajiban

3. Lebih familiar pada lebih banyak orang dan lebih komprehensif dalam penyajian informasinya

Dalam sistem akrual mau tidak mau harus diterapkan sistem alokasi yang umumnya dilakukan secara subjektif karena pembebanan biaya, pengakuan pendapatan, dan prinsip "matching"nya harus mematuhi prinsip "time period". Artinya jika beban biaya adalah untuk mendapatkan penghasilan atau pada periode tahun buku yang dilaporkan maka kendatipun belum dibayar harus diperhitungkan karena memang sudah merupakan hak atau kewajiban entitas. Jadi dalam basis akrual yang menjadi dasar pencatatan transaksi adalah hak dan kewajiban tanpa melihat apakah sudah diterima atau dibayar melalui transaksi kas atau tidak. adalah:

Dasar penggunaan Accrual Basis

1. Menurut PSAK 101 : “ Entitas syariah harus menyusun laporan keuangan atas dasar akrual, kecuali Laporan Arus Kas dan penghitungan pendapatan untuk tujuan pembagian hasil usaha. Dalam penghitungan pembagian hasil usaha didasarkan pada pendapatan yang benar-benar terjadi (cash basis)."

2. Dalam Al-Qur'an Surat Al-Baqarah : 282

" Hai orang-orang yang beriman apabila kamu melakukan transaksi secara utang untuk masa yang akan datang maka catatkanlah (bukukanlah)."

Dalam ayat tersebut seakan terlihat memberikan panduan mencatat suatu transaksi secara accrual basis, terlebih lafaz 'faaktubuh' diartikan dengan 'bukukanlah'.

Dalam bahasa akuntansi 'membukukan' berarti mengakui sebagai pendapatan. Metode accrual basis ini juga 
seperti yang pernah dilakukan semasa Khalilfah 'Utsman bin 'Affan, di mana piutang (yang belum diterima kreditur) dapat diperhitungkan sebagai objek zakat. Sebagian fuqaha menyetujui cara ini sebagai langkah ihtiyaath (berhati-hati) dan tazkiyyah (penyucian harta). Prinsip accrual basis ini semakin mendapat argumen ketika kita mengamati bahwa pihak yang diperintah (mukhatab) oleh Q.S. Al Baqarah ayat 2:282 ini adalah pihak kreditur dan debitur. Dari perspektif akuntansi hal ini dapat berarti pendapatan dan biaya dapat diakui secara accrual basis.

Berdasarkan keterangan tersebut di atas, maka dapat disimpulkan bahwa pendapatan dan beban dalam accrual basis diakui pada saat terjadinya transaksi dan dicatat untuk suatu periode, sehingga mengakui adanya konsep realisasi dan penyesuaian.

Terdapat beberapa artikel terkait dengan penggunaan metode Cash Basis diantaranya adalah: Dasar Akrul VS Dasar Kas oleh Anhar, Cash atau Accrual oleh Cecep Maskanul Hakim, Dasar Akrual VS Dasar Kas Studi pendapat Para Ahli oleh Muhammad Surya, PSAK 59 : Syukur Namun Perlu Disempurnakan, Accrual dan Cash Basis Masing-masing Ada Tempatnya, dan Antara Cash dan Accrual Basis oleh Dedy. Masing-masing artikel tersebut dibahas tentang bagaimana penggunaan serta kelemahan dan keunggulan dari masingmasing metode pencatatan akuntansi yaitu metode Cash dan Accrual Basis.

\section{Akuntansi Akrual Dalam Penyusunan Laporan Keuangan Entitas Syariah}

Ikatan Akuntan Indonesia (2007) menyatakan bahwa tujuan laporan keuangan bank syariah pada dasarnya sama dengan tujuan laporan keuangan secara umum yaitu menyediakan informasi yang menyangkut posisi keuangan, kinerja dan perubahan posisi keuangan suatu perusahaan yang bermanfaat bagi sejumlah besar pemakai dalam pengambilan keputusan ekonomi.
Namun laporan keuangan bank syariah memiliki beberapa tambahan antara lain menyediakan:

a. Informasi kepatuhan bank terhadap prinsip syariah, serta informasi pendapatan dan beban yang tidak sesuai dengan prinsip syariah bila ada dan bagaimana pendapatan tersebut diperoleh serta penggunaannya

b. Informasi untuk membantu mengevaluasi pemenuhan tanggung jawab bank terhadap amanah dalam mengamankan dana, menginvestasikannya pada tingkat keuntungan yang layak, dan informasi mengenai tingkat keuntungan investasi yang diperoleh pemilik dan pemilik dana investasi terikat; dan

c. Informasi mengenai pemenuhan fungsi sosial bank, termasuk pengelolaan dan penyaluran zakat.

Pernyataan Standar Akuntansi Keuangan Perbankan Syariah di Indonesia dan KDPPLKS, yang merupakan hasil kerjasama antara Ikatan Akuntan Indonesia (IAI) dengan Bank Indonesia (BI) yang berisi aturan tentang Akuntansi Perbankan Syariah dan entitas syariah lain menyebutkan bahwa untuk mencapai tujuannya, laporan keuangan disusun atas dasar akrual. Dengan dasar ini, pengaruh transaksi dan peristiwa lain diakui pada saat kejadian (dan bukan pada saat kas atau secara kas diterima atau dibayar) dan diungkapkan dalam catatan akuntansi serta dilaporkan dalam laporan keuangan pada periode bersangkutan.

Menurut Adnan, dasar akrual memberikan hasil laporan keuangan yang lebih mendekati realitas dari kinerja suatu entitas dibandingkan dasar kas dimana laporan keuangannya tidak menunjukkan hasil kinerja entitas yang sesungguhnya atau kecenderungannya menunjukkan hasil yang lebih rendah dari sebenarnya 5 . Dengan itu

\footnotetext{
${ }^{5}$ Akhyar Adnan
} 
dasar kas tidak semestinya diterapkan dalam penyusunan laporan keuangan entitas syariah. Para praktisi akuntan yang terwakili dalam IAI bersepakat bahwa dasar akrual tidak menyimpang dari hukum Islam dengan itu bisa digunakan sebagai dasar dalam penyusunan laporan keuangan syariah.

PSAK Syariah yang disusun oleh Dewan standar akuntansi Indonesia sebagian besar masih merujuk pada standar akuntansi yang dibuat oleh AAOIFI (Accounting and Auditing Organization for Islamic Financial Institution) sebuah organisasi yang mengembangkan akuntansi dan auditing bagi lembaga keuangan syariah di tingkat dunia. AAOIFI menerapkan dasar akrual dalam penyusunan laporan keuangan lembaga keuangan syariah. Konsep akrual ini diterima AAOIFI dengan mengacu pada pendapat dari Umar bin Khattab (Napier,2007) : "Nilailah barang daganganmu dan bayarlah zakatnya (jika telah masuk nisab dan haulnya)". Hal ini memberi implikasi bahwa zakat harus dibayar atas kekayaan yang meningkat dan konsep ini paling baik untuk menilai kekayaan ${ }^{6}$.

Adapun alasan penggunaan dasar akrual yakni laporan keuangan dapat diperbandingkan dengan laporan keuangan lembaga lainnya, karena secara umum semua prinsip yang dianut dalam laporan keuangan adalah konsep dasar akrual ${ }^{7}$.

\section{Gharar dalam Accrual Basis}

Penolakan penerapan dasar akrual dalam penyusunan laporan keuangan entitas syariah telah dikemukakan oleh beberapa pemerhati akuntansi Islam dengan alasan bahwa dasar akrual tidak sesuai dengan syariah karena adanya unsur gharar. Dimana unsur gharar dalam akuntansi akrual menyangkut adanya unsur ketidakpastian dalam pengakuan pendapatan. Sebagaimana diketahui akuntansi akrual ini mengakui

\footnotetext{
${ }^{6}$ Nurhayati, Sri \& Wasilah. 2008. Akuntansi Islam di Indonesia. Jakarta: Salemba Empat, h. 115

${ }^{7}$ Batubara
}

pendapatan dan beban pada saat terjadinya aktivitas usaha bukan pada saat realisasi kasnya. Kelemahan dasar akrual dalam keandalan penyajian laporan keuangan disebabkan salah satunya adalah keleluasaan akrual yang memberikan oportunitis manajer untuk melakukan earning management.

\section{Implementasi Penggunaan Metode Pencatatan Cash Basis Dan Accrual Basis Pada Transaksi-Transaksi Di Bank Syariah}

Berdasarkan hasil temuan kami pada bank-bank syariah yang menjadi objek penelitian yaitu Bank Jabar Banten Syariah, Bank Muamalat, dan Bank Syariah Mandiri maka dapat disimpulkan bahwa saat ini bank syariah telah menggunakan metode pencatatan accrual basis dalam mencatat setiap transaksi-transaksinya.

Dengan dasar akrual, pengaruh transaksi dan peristiwa lain diakui pada saat kejadian (dan bukan pada nsaat kas atau setara kas diterima atau dibayar) serta diungkapkan dalam catatan akuntansi dan dilaporkan dalam laporan keuangan periode berjalan. Laporan keuangan yang disusun atas dasar akrual memberikan kepada pemakai tidak hanya transaksi masa lalu yang melibatkan penerimaan atau pengeluaran kas, tetapi juga kewajiban pembayaran kas di masa depan serta sumber daya yang merepresentasikan kas yang akan diterima di masa depan (KDPPLKS paragraf 4).

Metode accrual basis mereka gunakan untuk mencatat semua transaksi seperti: Transaksi Penghimpunan Dana ( tabungan mudharabah, tabungan wadiah, giro wadiah, giro mudharabah, dan deposito mudharabah), Transaksi Investasi Mudharabah, Transaksi Investasi Musyarakah, Transaksi Murabahah, Transaksi Salam dan salam Paralel, Transaksi Istishna dan Istishna Paralel, dan Transaksi Ijarah serta Ijarah Muntahiyah Bittamlik (IMBT).

Hal tersebut dilakukan atas dasar: 
1. Menurut PSAK 101 : “ Entitas syariah harus menyusun laporan keuangan atas dasar akrual, kecuali Laporan Arus Kas dan penghitungan pendapatan untuk tujuan pembagian hasil usaha. Dalam penghitungan pembagian hasil usaha didasarkan pada pendapatan yang benar-benar terjadi (cash basis)."

2. Dalam Al-Qur'an Surat Al-Baqarah : 282

" Hai orang-orang yang beriman apabila kamu melakukan transaksi secara utang untuk masa yang akan datang maka catatkanlah (bukukanlah)."

Metode cash basis mereka gunakan dalam perhitungan bagi hasil yang akan dibayarkan dengan cara merekonsiliasi pendapatan atas dasar akrual dari setiap transaksi menjadi bentuk pencatatan cash basis agar pendapatan tersebut mencerminkan pendapatan yang benar-benar terealisasi untuk kemudian dibagikan kepada nasabah dan bank sesuai nisbah yang ditentukan sebelumnya.

Adapun perlakuannya yaitu dengan merekonsiliasi pendapatan dari transaksitransaksi yang dicatat dengan basis akrual menjadi basis kas agar untuk keperluan pembagian hasil sesuai nisbah yang telah ditentukan sebelumnya di akad setiap transaksi yang dilakukan antara bank dan nasabahnya.

Terminologi laporan ini diperoleh dari pernyataan yang ada di PSAK Syariah Nomor 101 tentang Penyajian Laporan KeuanganSyariah yang dikeluarkan oleh Ikatan Akuntan Indonesia. Pernyataan ini berdasarkan asumsi bahwa pencatatan transaksi-transaksi yang dilakukan oleh perbankan syariah menggunakan basis akrual. Padahal dalam rangka pembagian hasil usaha diperlukan informasi mengenai kinerja perbankan syariah yang diperoleh dari perhitungan dengan dasar kas sehingga menunjukkan bagi hasil yang sebenarnya menjadi hak mudraib dan shahibulmaal dalam akad mudharabah. Oleh karena itu, perhitungan laporan laba rugi dan pengakuan pendapatan perlu dilakukan upaya konversi dari akrual menjadi berbasis kas. Hal ini dilakukan karena perbankan syariah tidak dibenarkan mendistribusikan pendapatan atau keuntungan yang bukan menjadi hak perbankan syariah. Dengan kata lain, pendapatan atau keuntungan yang sifatnya masih pengakuan dan belum secara riil diterima oleh perbankan syariah tidak diperkenankan untuk dijadikan dasar untuk perhitungan porsi bagi hasil usaha. Laporan ini akan mengeliminasi pendapatan yang diperoleh berdasarkan basis akrual dan mengakui pendapatan yang seharusnya diperoleh pada periode berjalan.

\section{Penerapan Pencatatan Akuntansi Sesuai Prinsip Syariah}

Dengan terbitnya UU No. 10/1998 tentang perbankan menjadi konsekuensi logis harus diterapkannya prinsip-prinsip syariah Islam dalam mekanisme perbankan. Akutansi Islam adalah akuntansi yang menerapkan prinsip-prinsip syariah dalam operasionalnya. . Akuntansi Islam telah diatur dalam PSAK 101-110 yang didalamnya memuat pengakuan, pengukuran, penyajian dan pengungkapan suatu transaksi muamalah. Menurut Undang-undang No.10 Tahun 1998, prinsip syariah diartikan sebagai berikut:

"Prinsip syariah adalah aturan perjanjian berdasarkan hukum Islam antara bank dan pihak lain untuk penyimpan dana dan /atau pembiayaan kegiatan usaha, atau kegiatan lainnya yang dinyatakan sesuai dengan syariah, antara lain, pembiayaan berdasarkan prinsip bagi hasil (mudharabah), pembiayaan berdasarkan prinsip penyertaan modal (musyarakah), prinsip jual beli barang dengan memperoleh keuntungan (murabahah) atau pembiayaan barang modal berdasarkan prinsip sewa murni tanpa pilihan (ijarah), atau dengan adanya pilihan pemindah kepemilikam atas barang yang disewa dari pihak bank oleh pihak lain (ijarah wa iqtina)."

Melihat pengertian prinsip-prinsip syariah menurut UU no. 10 tahun 1998, kita dapat mengetahui bahwa sebenarnya prinsi- 
prinsip syariah bersumber pada aturan-aturan Islam, baik itu Al Qur'an, Hadist, Ijma sahabat maupun Qiyas Syar'iyyah. Kepatuhan syariah sendiri adalah keterikatan akan hukum-hukum syariah Islam, sedangkan kepatuhan prinsip-prinsip syariah dapat diartikan sebagai kepatuhan akan prinsip-prinsip syariah yang bersumber pada kaidah hukum Islam. Sehingga dapat kita simpulkan bahwa tujuan dari akuntansi Islam adalah untuk mendorong kepatuhan prinsip-prinsip syariah.

Berdasarkan temuan kami dilapangan, dapat kami simpulkan bahwa bank syariah dalam pencatatan transaksi-transaksinya telah mematuhi prinsip-prinsip syariah yaitu dengan berpedoman pada PSAK No. 101110 tentang Perbankan Syariah. Yaitu secara umum bahwa transaksi-transaksi di bank syariah dicatatat berdasarkan metode pencatatan atas dasar akrual, kecuali Laporan Arus Kas dan penghitungan pendapatan untuk tujuan pembagian hasil usaha. Dalam penghitungan pembagian hasil usaha didasarkan pada pendapatan yang benar-benar terjadi yaitu dengan menggunakan metode pencatatan cash basis.

\section{Implikasi Penggunaan Metode Pencatatan Cash Basis dan Accrual Basis}

Dalam metode cash basis, pendapatan diakui ketika cash diterima sedangkan beban diakui pada saat cash dibayarkan, artinya perusahaan mencatat beban didalam transaksi jurnal entry ketika kas dikeluarkan atau dibayarkan dan pendapatan dicatat ketika kas masuk atau diterima. Beban dalam metode accrual basis diakui pada saat pendapatan diakui. Metode akuntansi yang digunakan suatu perusahaan dapat mempengaruhi pendapatan total suatu perusahaan pada laporan keuangannya, begitu pula dengan beban perusahaan. Didalam metode cash basis beban tidak diakui sampai uang dibayarkan walaupun beban terjadi terjadi pada bulan itu. Demikian juga dengan pendapatan, tidak diakui sampai dengan uang diterima. Sehingga metode cash basis tidak mencerminkan besarnya uang yang ada sebenarnya. Pada metode accrual basis beban dan pendapatan diakui pada saat terjadinya transaksi. Sehingga informasi yang disediakan lebih handal dan terpercaya tentang seberapa besar suatu perusahaan mengeluarkan uang atau menerima uang dalam setiap bulannya. Pencatatan menggunakan metode ini mengakui beban pada saat transaksi terjadi walaupun kas belum dibayarkan. Begitu pula dengan pendapatan, dicatat pada saat transaksi terjadi walaupun kas atas transaksi pendapatan tersebut baru diterima bulan depan.

Sehingga dapat disimpulkan bahwa pencatatan menggunakan metode accrual basis lebih mencerminkan keadaan keuangan perusahaan sebenarnya. Tetapi metode pencatatan accrual basis lebih sulit untuk diterapkan karena akuntan harus melakukan pencatatan lebih banyak dibandingkan dengan menggunakan metode cash basis.

Basis kas akan melahirkan informasi tentang likuiditas yang sangat perlu bagi para pengambil keputusan. Akuntansi berbasis akrual sangat perlu untuk menyusun laporan laba rugi dan laporan posisi keuangan (neraca). Bahkan laporan kontinjensi pada industri perbankan yang berbasis risiko masa depan juga perlu disajikan apalagi dalam situasi ekonomi yang semakin tidak pasti seperti yang jelas dipraktekkan khususnya dalam industri perbankan.

\section{Penutup dan Kesimpulan}

Berdasarkan hasil penelitian maka dapat disimpulkan bahwa: Metode pencatatan Cash Basis adalah basis akuntansi yang mengakui pengaruh transaksi dan peristiwa lainnya pada saat kas atau setara kas diterima atau dibayar yang digunakan untuk pengakuan pendapatan, belanja dan pembiayaan, sedangkan pendapatan dan beban dalam accrual basis diakui pada saat terjadinya transaksi dan dicatat untuk suatu periode, sehingga mengakui adanya konsep realisasi dan penyesuaian. 
Saat ini bank syariah secara umum telah mencatat transaksi-transaksi berdasarkan metode pencatatan atas dasar akrual, kecuali Laporan Arus Kas dan penghitungan pendapatan untuk tujuan pembagian hasil usaha. Metode cash basis mereka gunakan dalam perhitungan bagi hasil yang akan dibayarkan dengan cara merekonsiliasi pendapatan atas dasar akrual dari setiap transaksi menjadi bentuk pencatatan basis kas, Hal ini dilakukan karena perbankan syariah tidak dibenarkan mendistribusikan pendapatan atau keuntungan yang bukan menjadi hak perbankan syariah. Laporan ini akan mengeliminasi pendapatan yang diperoleh berdasarkan basis akrual dan mengakui pendapatan yang seharusnya diperoleh pada periode berjalan.

Bank syariah dalam pencatatan transaksi-transaksinya telah mematuhi prinsip-prinsip syariah yaitu dengan berpedoman pada PSAK No. 101-110 tentang Perbankan Syariah. Yaitu secara umum bahwa transaksi-transaksi di bank syariah dicatatat berdasarkan metode pencatatan atas dasar akrual, kecuali Laporan Arus Kas dan penghitungan pendapatan untuk tujuan pembagian hasil usaha. Dalam penghitungan pembagian hasil usaha didasarkan pada pendapatan yang benar-benar terjadi yaitu dengan menggunakan metode pencatatan cash basis.

Implikasi dari penggunaan metode pencatatan menggunakan metode accrual basis lebih mencerminkan keadaan keuangan perusahaan sebenarnya. Tetapi metode pencatatan accrual basis lebih sulit untuk diterapkan karena akuntan harus melakukan pencatatan lebih banyak dibandingkan dengan menggunakan metode cash basis. Sedangkan penggunaan metode pencatatan basis kas akan melahirkan informasi tentang likuiditas yang sangat perlu bagi para pengambil keputusan. Akuntansi berbasis akrual sangat perlu untuk menyusun laporan laba rugi dan laporan posisi keuangan (Neraca). Bahkan laporan kontinjensi pada industri perbankan yang berbasis risiko masa depan juga perlu disajikan apalagi dalam situasi ekonomi yang semakin tidak pasti seperti yang jelas dipraktekkan khususnya dalam industri perbankan.

Adapun saran yang dapat kami berikan berdasarkan hasil temuan kami dilapangan adalah bahwa pihak bank syariah perlu lebih memahami prinsip-prinsip dasar pencatatan yang berbasis prinsip-prinsip syariah serta perlu ada pemahaman lebih mendalam terkait penerapan Standar Akuntansi Keuangan (SAK) khususnya SAK Syariah di bank syariah bagi para pegawai khususnya dibagian akuntansi.

\section{Daftar Pustaka}

Dewan Syari'ah Nasional Majelis Ulama Indonesia. 2006. Himpunan Fatwa Dewan Syari'ah Nasional, Edisi Ketiga. Jakarta: Dewan Syari'ah Nasional Majelis Ulama Indonesia.

DSAK IAI, 2007. “ Kerangka Dasar Penyusunan dan Penyajian Laporan keuangan Syariah ". Jakarta: IAI dan Penerbit Salemba.

DSAK IAI, 2007. “ Peryataan Standar Akuntansi Keuangan No. 101 tentang Penyajian Laporan Keuangan. Jakarta: IAI dan Penerbit Salemba.

DSAK IAI, 2007. “ Peryataan Standar Akuntansi Keuangan No. 102 tentang Akuntansi Murabahah. Jakarta: IAI dan Penerbit Salemba.

DSAK IAI, 2007. “ Peryataan Standar Akuntansi Keuangan No. 103 tentang Akuntansi Salam. Jakarta: IAI dan Penerbit Salemba.

DSAK IAI, 2007. “ Peryataan Standar Akuntansi Keuangan No. 104 tentang Akuntansi Istishna. Jakarta: IAI dan Penerbit Salemba.

DSAK IAI, 2007. “ Pernyataan Standar Akuntansi Keuangan No. 105 tentang 
Akuntansi Mudharabah. Jakarta: IAI dan Penerbit Salemba.

DSAK IAI, 2007. “ Peryataan Standar Akuntansi Keuangan No. 107 tentang Akuntansi Ijarah. Jakarta: IAI dan Penerbit Salemba.

Antonio, Muhammad Syafii.2001. Bank Syariah, dari Teori ke Praktik. Jakarta: Tazkia Cendekia.

Yaya, Rizal, Aji Erlangga Martawireja, dan Ahim Abdurahim. 2009. Akuntansi Perbankan Syariah: Teori dan Praktek Kontemporer. Jakarta: Salemba Empat.

Nurhayati, Sri \& Wasilah. 2008. Akuntansi Islam di Indonesia. Jakarta: Salemba Empat.

Karim, Adiwarman A. 2004. Bank Islam: Analisis Fiqh dan Keuangan. Edisi Kedua. Penerbit Rajawali. Jakarta.

Mulawarman, Aji Dedi. 2007. Menggagas laporan arus kas syariah berbasis ma'isyah diangkat dari Habitus Bisnis Muslim Indonesia. Makalah disampaikan dalam Simposium Nasional Akuntansi X Tahun 2007.

Maskanul, Cecep H. Problem Pengembangan Produk Dalam Bank Syariah. Makalah disampaikan dalam Buletin Ekonomi Moneter dan Perbankan edisi bulan Desember 2002

Baraba, Ahmad. 2002. Perkembangan Akuntansi Bank Syariah. Makalah. Seminar Nasional Akuntansi Syariah Shariah Economics Forum FE UGM, IMAGAMA, dan IMAK, Gedung Pasca Sarjana UGM, 2 Maret 2002.

Waluyo, Bambang. 2006. Dampak perusahaan dasar pengakuan pendapatan margin murabahah terhadap pendapatan operasi utama, profitabilitas dan distribusi bagi hasil $\mathrm{pt}$ bank syariah muamalat Indonesia tbk.
Harahap, Sofyan S. 2001. Мепијu Perumusan Teori Akuntansi Islam. Pustaka Quantum. Jakarta.

Lathifah, ifah. 2007. Model Alternatif Akuntansi Syariah dalam Pelaporan Keuangan

Sugiono.2009. Metode Penelitian Kuantitatif, Kualitatif dan $R \quad \& \quad D$. Bandung: CV. Alfabeta

Harahap, Sofyan S., dan Yusuf M. Wiroso. 2004. Akuntansi Perbankan Syariah. Jakarta: IAI 